\title{
Characteristic of Milkfish (Chanos - Chanos Forks) Bone Nanocalcium by Acids and Alkaline Extraction
}

\author{
Muhammad Fitri ${ }^{1,2}$, Mursalim $^{3}$, Amran Laga $^{3}$, and Zainal ${ }^{3}$ \\ ${ }^{*}$ Post-Graduate Student, Hasanuddin University, Makassar, South Sulawesi, Indonesia \\ ${ }^{2}$ Department of Fishery Product Processing Technology, Pangkep State Polytechnic of Agricultural, Pangkep, \\ South Sulawesi, Indonesia \\ ${ }^{3}$ Department of Agricultural Engineering and Food Technology, Hasanuddin University Makassar, South \\ Sulawesi, Indonesia
}

\begin{abstract}
Milkfish is a fishery commodity in Pangkep regency of South Sulawesi Province. Milkfish production in 2011 was 585,242 tons Directorate General Ocean and Fishery (2012). Utilization of milkfish bone waste as a source of calcium is an alternative in providing a rich source of calcium as well as reducing the negative impact of environmental pollution. Calcium derived from animals such as fish bone waste so far has not been widely used for human needs. The purpose of this research is to study the quality of milkfish bone nano calcium with the acid and alkaline extraction method. The treatment in this study are alkaline solution (A) $A_{1}=2$ percentage, $A_{2}$ $=3$ percentage and $\mathrm{A}_{3}=4$ percentage, acid solution (B) $\mathrm{B}_{1}=2$ percentage, $\mathrm{B}_{2}=3$ percentage and $\mathrm{B}_{3}=4$ percentage. The design used is complete randomized design with two factors. Each treatment was repeated three times. The data analyzed by variance analysis using SPSS V. 19 software. Research result of milkfish bone nano calcium By using alkaline and acid extraction the best milkfish bone nano calcium is alkaline extraction with 40 percent $\mathrm{NaOH}$ cooking at temperature $100^{\circ} \mathrm{C}$ for 60 minutes where the water content is 5.21 percentage. The ash content is 52.87 percentage, the calcium content is 46.13 percentage, the protein content is 2.04 percentage and the color sensory test is 3.9 (likes) and the aroma is 4.6 (very like).
\end{abstract}

Keywords : Extraction, Milkfish, Nano Calcium

\section{INTRODUCTION}

The production of milkfish has increased from 20072011 by 263,139 tons (2007), 277,471 tons (2008), 328,288 tons (2009), 421,757 (2010) and 585,242 tons (2011), with an increase of 38.76 percentage 20102011 Ocean and Fishery Ministery (2011). Milkfish is a fishery commodity of Pangkep regency in South Sulawesi Province. Increasing the value of milkfish production increased from year to year with a fairly sharp value. With the increase of milkfish consumption, there is also an increase in bone waste volume of milkfish who not much benefit . Utilization of milkfish bone waste as a source of calcium is an alternative in order to provide calcium rich food source as well as reduce the negative impact of environmental pollution (Hafiludin, 2015). Calcium derived from animals such as fish bone waste so far has not been widely used for human needs. Though fish bones contain tri calcium phosphate which is ideal for the human body (Basmal $\mathrm{J}$, et all, 2000 ). Calcium requirement is $500 \mathrm{mg}$ day ${ }^{-1}$ for ages $1-9$ years, $700 \mathrm{mg}$ day $^{-1}$ for ages $10-15$ years, $600 \mathrm{mg} \mathrm{day}^{-1}$ for ages $16-19$ years and 500-800 mg day 
${ }^{-1}$ for adults (age 20 to over 60 years) (Almatsier, 2004).

Bone is one form of waste generated from the fish processing industry that has the highest content of calcium in the fish body. From a food and nutritional standpoint, fish bones are rich calcium that needed human , because the main elements of fish bones are calcium, phosphorus and carbonate. Thus, fish bone waste has great potential to be utilized as a raw material of fish bone rich in calcium. Fish bones contain a lot of mineral salts such as calcium phosphate and creatine phosphate which has the potential to increase the nutrients of food products (Maulida, N. 2005).

The aim of this research is to study the quality of nanocalcium from bone of milkfish (Chanos - Chanos Forks), By using the alkaline and acid solution.

\section{METHODS AND MATERIAL}

\section{A. Research Site}

It was carried out at the Chemical Laboratory of State Agricultural Polytechnic of Pangkep and Plant Assessment Center of Makassar

\section{B. Materials and Tools}

\section{Material}

In this study the materials used were bone of milkfish, $\mathrm{HCl}, \mathrm{NaOH}, \mathrm{pH}$ paper and chemicals $\mathrm{NaOH}$ $0.1 \mathrm{~N}, \mathrm{MgSO}_{4}, \mathrm{HCl} 0.01 \mathrm{~N}, \mathrm{H}_{2} \mathrm{BO}_{3}, \mathrm{Na}_{2} \mathrm{~S}_{2} \mathrm{O}_{3}, \mathrm{HgO}$, Neutral Alcohol, PP Indicators, distilled water and some Zink, etc.

\section{Tools}

The tools used in the processing procedure are stoves, knives, blenders, pans, basins, grinders, digital scales, packaging. While the tools for chemical analysis are
Erlenmeyer, Kjeldhal flask, test tube, condenser, oven, boiling rock, distillation flask, exicator, buret and others as needed in research

\section{Sample Preparation}

This research will be conducted for two years. The first year is to analyze the quality of milkfish bone nano calcium by using alkaline solution by treatment $A_{1}=2$ percentage, $A_{2}=3$ percentage and $A_{3}=4$ percentage and to analyze the quality of milkfish bone nano calcium by using acid solution by treatment. $\mathrm{B}_{1}=2$ percentage, $\mathrm{B}_{2}=3$ percentage and $\mathrm{B}_{3}$ $=4$ percentage.

The research design used was complete randomized design, With two factors. Each treatment was repeated three times. The observation data analyzed by variance analysis using SPSS V. 19 software. If the results of the variance analysis show a significant or very significant effect, then the middle value tested by using Honestly Significant Difference test. Parameters under observation is water, ash, protein, calcium and sensory test (color, aroma, and texture).

The tests conducted to determine the nano calcium quality, which are physicochemical characterization of each. Chemical composition test including water content with the oven method (AOAC,2000), ash content (AOAC,2000), protein content by Kjeldahl method (AOAC,2000), Calcium content (Sudarmadji1984)

\section{Processing Procedures}

Raw materials (milkfish bone powder), to produce raw materials of bones ready for extracted milkfish have gone through several stages of the process such as washing, boiling ( $80{ }^{\circ} \mathrm{C}, 30$ minute), Washing, Autoclaving $\left(121^{\circ} \mathrm{C}, 1 \mathrm{~atm}, 1\right.$ hour), and reducing the size using a hammer mill $( \pm 5 \mathrm{~cm})$. The second stage is 
Boiling $\left(100{ }^{\circ} \mathrm{C}, 30\right.$ minute, 1 frequency) the extraction of milkfish bones by using two different solvents, alkaline $(\mathrm{NaOH})$ and acid $(\mathrm{HCl})$ solution separately,Washing, drying and milling which aims to soften the fish bones so as to facilitate the process of flouring (Nabil, M. 2005).

\section{Extraction with alkaline solution $(\mathrm{NaOH})$}

Treatment $\mathrm{A}$ is 100 percentage rough powdered bone of milkfish was extracted with a $1 \mathrm{~N} \mathrm{NaOH}$ (Merck) solution with $A_{1}=2$ percentage, $A_{2}=3$ percentage and $A_{3}=4$ percentage at $100^{\circ} \mathrm{C}$ for 60 minutes. This extraction process repeated 3 times. The extraction results are then cooled, filtered, neutralized to neutral $\mathrm{pH}$ and dried by oven at $50^{\circ} \mathrm{C}$ to a water content of $<8$ percentage.

\section{Extraction with acid solution $(\mathrm{HCl})$}

Treatment B is 100 percentage rough powdered milkfish bone is hydrolyzed using $\mathrm{HCl}$ (Merck) $1 \mathrm{~N}$ with $\mathrm{B}_{1}=2$ percentage, $\mathrm{B}_{2}=3$ percentage and $\mathrm{B}_{3}=4$ percentage ,Then extracted at $100^{\circ} \mathrm{C}$ for 60 minutes. The extraction process was repeated 3 times and the extraction result was then cooled, filtered and neutralized using distilled water up to a neutral $\mathrm{pH}$ sample, then dried in oven at $50^{\circ} \mathrm{C}$ until it reaches the water content of $<8$ percentage. extracted Milkfish bone powder that extracted using $\mathrm{NaOH}$ and $\mathrm{HCl}$ then made into flour using a disc mill then sieved using 100 mesh size. Sterilization process carried out at $121^{\circ} \mathrm{C}$ for 15 minutes to maintain the quality and extend the shelf life of the resulting bone powder

\section{Test Parameters}

\section{Water content of oven method (AOAC,2000)}

Determination of water content based on the difference in weight for example before and after dried. At first the empty cup is dried in the oven for 30 minutes at $105^{\circ} \mathrm{C}$. then cooled in the eksikator for 15 minutes, Then weighed. 3-5 gram of sample inserted into the cup then dried in $105^{\circ} \mathrm{C}$ oven for 6 hours. Cup cooled in eksikator for 30 minutes, then weighed. The water content determined by the formula

$$
\text { Water Content }(\%)=\frac{B-C}{B-A} \times 100 \%
$$

\section{Ash content of gravimetric method (AOAC,2000)}

3-5 grams of sample weighed and put into the cup, then burned in the Bunsen until no smoke. After it inserted in a furnace, burned to gray ash. Ash carried out in two stages, first at a temperature of $400^{\circ} \mathrm{C}$ and then a temperature of $550^{\circ} \mathrm{C}$. After the weight of the cup is constant, the cup then cooled in a desiccator and weighed. Ash content determined by the formula:

$$
\text { Ash Content }(\%)=\frac{A}{B} \times 100 \%
$$

\section{Calcium Content (Williard's way) in Sudarmadji1984}

The residual solution obtained shall not contain calcium greater than $0.5 \mathrm{~g}$, if more then dilute to the specified volume, then take as much as $70 \mathrm{ml}$ for the determined $\mathrm{K}$ content contained in $70 \mathrm{ml}$ of Solution, add $5 \mathrm{ml}$ of per chlor acid solution $\left(\mathrm{HClO}_{4}\right) 20 \%$ (Specific gravity: 1.12) steam above the water bath slowly.

Add $10 \mathrm{ml}$ of hot distilled water and $5 \mathrm{ml}$ (HClO4) and $20 \%$ more above the water bath until a thick dense acid vapor arises. Cool to below room temperature, then add the washing alcohol solution. Wash with $3 \times 10 \mathrm{ml}$ washing alcohol solution, dried in oven temperature $130^{\circ} \mathrm{C}$ for 1 hour, then weighed. The weighted residue is $\mathrm{KClO}_{4}$

Weight $(\mathrm{g})=0,2821 \mathrm{x}$ weight $\mathrm{KClO}_{4}(\mathrm{~g})$ 


\section{Protein Content (AOAC,2000)}

Take $10 \mathrm{ml}$ of protein solution and diluted to $100 \mathrm{ml}$ with the distilled water in the flask, the solution is then put into a $500 \mathrm{ml}$ Kjeldahl flask and $10 \mathrm{ml}$ of $\mathrm{H}_{2} \mathrm{SO}_{4}(93 \%$ - 98\% free $\mathrm{N})$ add 5 grams of a mixture of $\mathrm{H}_{2} \mathrm{BO}_{3}, \mathrm{Na}_{2} \mathrm{SO}_{4}-\mathrm{HgO}$ for catalyst. Boil until clear and continued for another 30 minutes. After a cold washed in a Kjeldahl flask with distilled water then boiled again for 30 minutes.

Once cool add $140 \mathrm{ml}$ of distilled water, and added 35 $\mathrm{ml} \mathrm{NaOH}-\mathrm{Na} 2 \mathrm{~S} 2 \mathrm{O} 3$ and a few grains of zinc. Then it was distilled, $100 \mathrm{ml}$ of distillate accommodated in an erlenmeyer containing $25 \mathrm{ml}$ of boric acid saturated solution and a few drops of PP indicator. Solution obtained with $0.02 \mathrm{~N} \mathrm{HCl}$. The total $\mathrm{N}$ or percent (\%) of protein in the sample is calculated by the following equation

$\mathrm{N}$ Total $=\frac{\mathrm{ml} \mathrm{HCl} \times \mathrm{N} \mathrm{HCl}}{\mathrm{ml} \text { sample solution }}$

\section{Sensory Test (Soekarto S.T. 1985)}

Sensory tests include color, aroma and protein hydrolysate by "Consumer preference test" method in which the material is presented randomly after coded on a hedonic scale. The panelist is selected as much as possible, at least 15 persons to provide an assessment based on the preference degree to the sample presented and declare the judgment in the list. Panelist ratings range from Very like (5), likes (4), regular / Neutral (3), rather dislike (2), dislikes (1). Each panelist has a list of work procedures to be filled in accordance with the statement and panelist preferences.

\section{Data Analysis}

The research design used was complete randomized design, With two factors. Each treatment was repeated three times. The observation data analyzed by variance analysis using SPSS V. 19 software. If the results of the variance analysis show a significant or very significant effect, then the middle value tested by using Honestly Significant Difference test. Parameters under observation is water, ash, protein, calcium and sensory test (color, aroma, and texture).

\section{RESULTS AND DISCUSSION}

\section{a. Water Content Analysis Result of Milkfish Bone Nano Calcium}

Water content of food ingredients also determine the acceptability, freshness, and durability of food. The water content of food affects the durability of the food against microbial attack expressed by which is the amount of free water that can be used by microorganisms for growth (Sokartono.S.T., 1985).

Water is a major component in foodstuffs that greatly influence texture, appearance, and taste in food. The durability of processed materials also strongly related to the water content because it greatly affects the proliferation of microorganisms in processed products (Wardani.et all , 2012). The results of the water content of milkfish bone nano calcium with the treatment of alkaline and acid extraction ranged from 5.21 to 5.47 percentage with the average moisture content of fish bone nano calcium showed 5.34 percentage. .The highest water content obtained in the treatment of acid extraction method with 2 percentage $\mathrm{HCl}$ cooking with $100^{\circ} \mathrm{C}$ temperature for 60 minutes with value 5.47 percentage and the lowest water content obtained at alkaline extraction treatment with $\mathrm{NaOH} 1 \mathrm{~N} 4$ percentage with temperature $100^{\circ} \mathrm{C}$ for 60 minutes with value 5.21 percentage. 


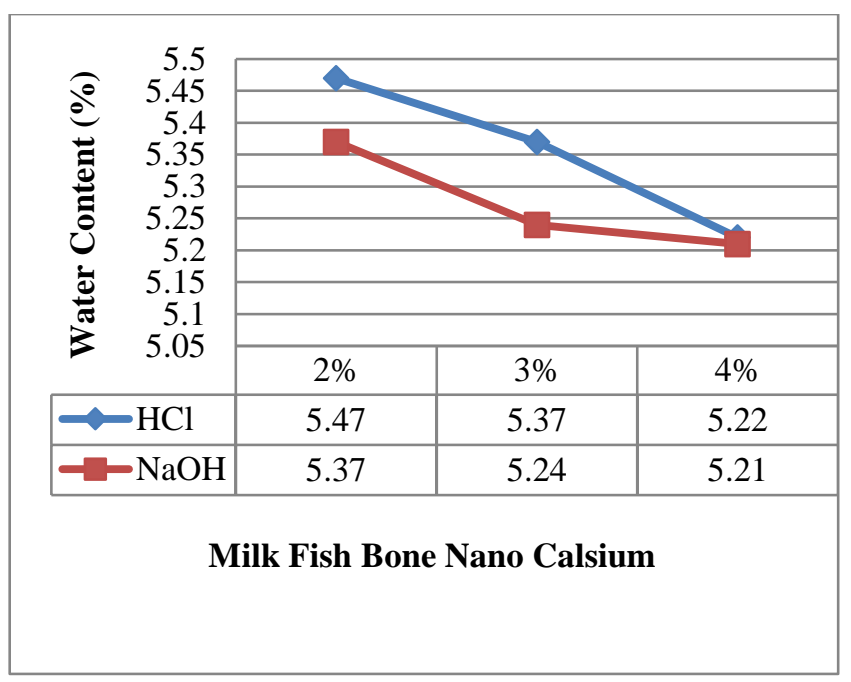

Figure 1. Water Content Analysis Result of Milkfish Bone Nano Calcium by Acid Alkaline Method

Figure 1 shows that the moisture content of milkfish bone nano calcium from all treatments still meets the water content standard specified by SNI 01-31581992 (DSN, 1992) that maximum 8 percentage, One of the methods that affect the water content in the material is drying process that drying with long sunlight because the temperature, humidity, and airflow rate can not be regulated in (Nabil, M. 2005)

Variance analysis result (Anova) on water content of milkfish bone nano calcium showed a significant difference between treatment $\mathrm{P}<0,05$ Variance analysis result of water content of milkfish bone nano calcium With treatment of acid-alkaline extraction significant value less than 5 percentage, Then $\mathrm{H}_{1}$ is accepted and $\mathrm{H}_{0}$ is rejected. This means there is a difference between the treatments tested.

\section{b. Ash Content Analysis Result of Milkfish Bone Nano Calcium}

Ash is one component in food ingredients. This component consists of minerals such as potassium, phosphorus, sodium, magnesium, calcium, iron, manganese, and copper (Wardani et all, 2012). The results of ash content of milkfish bone nano calcium with acid-alkaline extract treatment ranged from 48.94 to 55.56 percentage with the average value of 52.25 percentage.

Figure 2 shows ash content of all treatment increases. According to (Elfauziah R.2003), the main part in bone powder is the ash content that found 75 percentage. The highest ash content obtained on the treatment of alkaline extraction method by cooking $\mathrm{NaOH} 4$ percentage at temperature $100^{\circ} \mathrm{C}$ for 60 minutes with value 55,56 percentage and the lowest ash content obtained at treatment of acid extraction method with 2 percentage $\mathrm{HCl}$ cooking at temperature $100^{\circ} \mathrm{C}$ for 60 minute with a value of 48.94 percentage. The ash content of milkfish bone nano calcium in this research higher than the bone powder standard based on ISA standards (International Seafood of Alaska) 33.1 percentage But lower than the results of research conducted (Mulia. 2004) 63,5 percentage and (Elfauziah R.2003) 79,14 percentage.

The variance analysis result of ash content with treatment of acid-alkaline extraction method is significantly less than 5 percentage, $\mathrm{H}_{1}$ accepted and $\mathrm{H}_{0}$ rejected. This means that there is a difference between the treatments tested. The high ash content obtained from milkfish bone contains calcium elements that needed by the body. This is caused more and more high concentration alkaline before through the saturated point more and more high result the ash content, and kinds and much mineral be contained in the milkfish bone. The main ingredients of fish bone are calcium, sodium, strontium, chloride, hydroxide, and sulfate. Increased ash content influenced by the amount of burnt minerals into volatile substances. The highest ash content of a foodstuff means the highest mineral the food contains. While result research (Anggraeni N., 
et all ,2016) show the ash content nano calcium who produced 78.82 percentage and result research [11] (Lekahena V., et all. 2014.) is 85.44 percentage where both higher compared nanocalcium this research

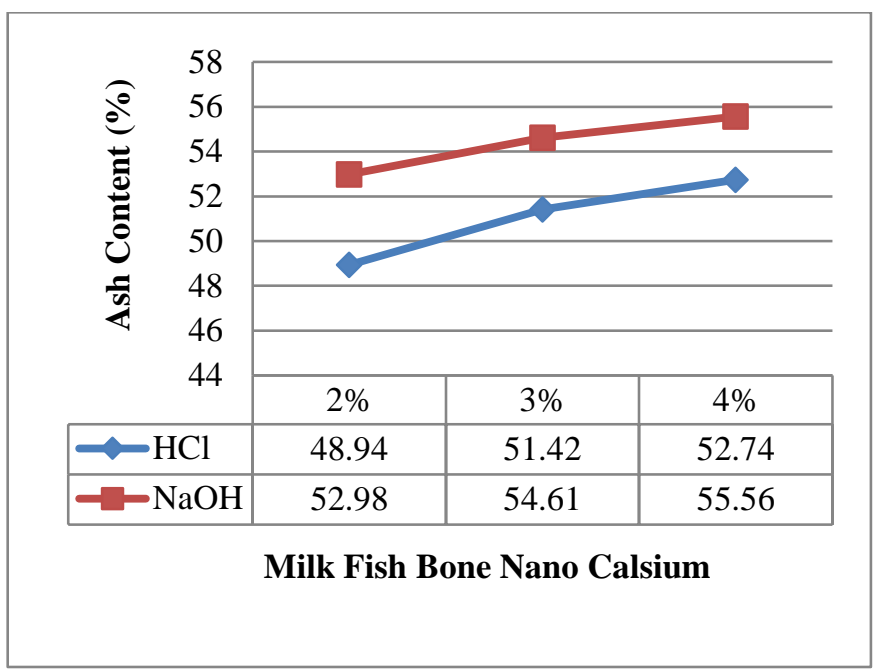

Figure 2. Ash Content Analysis Result of Milkfish Bone Nano Calcium by Acid Alkaline Method

This is caused content mineral of milkfish is low caused brackish fish. content ash on foodstuff influenced amount mineral who are in fish of the example mineral is calcium opinion [8] (Ferazumma $\mathrm{H}$., et all, 2011) .These many are influence content of mineral ,content ash influenced time duration autoclaving and frequency boiling the significant influence of ash content, protein and fat bone flour. . bone before processing content cell alive and intracellular matrics in form the salt mineral. Ash content who high in the bone flour caused by main component manage bone is mineral and process it's making had occur hydrolysis protein who almost total that produced protein the lowest.

\section{c. Calcium Content Analysis Result of Milkfish Bone Nano Calcium}

Calcium derived from animals such as fish bone waste so far has not been widely used for human needs. However, fish bones contain tri calcium phosphate, which is ideal for the human body (AOAC. 2000.)

Fish bone is one form of waste generated from the fish processing industry that has the highest content of calcium in the fish body. From a food and nutritional standpoint, fish bones are rich in calcium that humans need, because the main elements of fish bones are calcium, phosphorus and carbonate. Fish bones contain many mineral salts such as calcium phosphate and creatine-phosphate, which has the potential to increase the nutrients of food products (Maulida, N. 2005)

The calcium content analysis result of with acidalkaline extract treatment ranged from 42.94 to 49.89 percentage with the average 46.13 percentage .The highest calcium content obtained on the treatment of alkaline extraction method with 4 percentage $\mathrm{NaOH}$ cooking at $100^{\circ} \mathrm{C}$ temperature for 60 minutes with value 49.63 percentage and the lowest calcium content obtained in the treatment of acid extraction method with 2 percentage $\mathrm{HCl}$ cooking at $100^{\circ} \mathrm{C}$ temperature for 60 Minute with value 43.06 percentage.

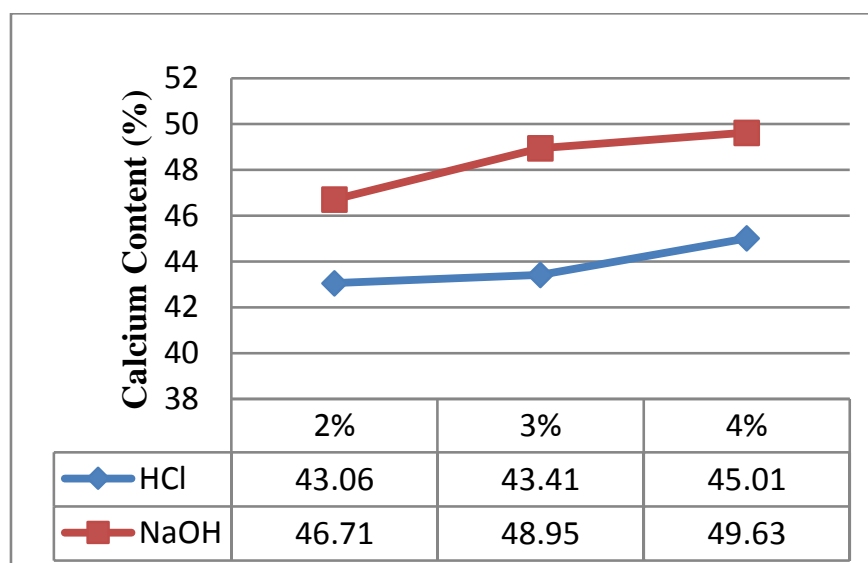

Milk Fish Bone Nano Calsium

Figure 3. Calcium Content Analysis Result of Milkfish Bone Nano Calcium by Acid Alkaline Method 
Figure 3 shows the calcium content of milkfish bone nano calcium from all treatments increase. According to calcium consumption should not exceed $2500 \mathrm{mg}$ day ${ }^{-1}$ (Almatsier. 2004).The results also showed that the higher the concentration of $\mathrm{HCl}$ and $\mathrm{NaOH}$ used, the higher the calcium content in the fish bone powder. Calcium is one of the most mineral in bone attached to collagen protein (Wardani, et all, 2012). In base condition, calcium in bone along with phosphorus forms calcium phosphate. Calcium phosphate is a mineral crystal that has insoluble properties in alkaline $\mathrm{pH}$ (Almatsier. 2004). Insoluble calcium during boiling will be left behind and settle in the matrices of the shell so as to increase the proportion of calcium in the Milkfish bone material.

The variance analysis result of calcium content with treatment of acid base extraction method significantly less than 5 percentage, then the $\mathrm{H}_{1}$ accepted and $\mathrm{H}_{0}$ rejected. This means that there are differences between treatments tested. This is presumably the higher the temperature the higher the calcium content. The best calcium content is by the $\mathrm{NaOH}$ method made possible by the high temperature extraction used in the $\mathrm{NaOH}$ solution, which will allow the amount of calcium to settle in bone matrices, so that the calcium powder of fish bones will increase. This is reinforced by the statement of Harrow and Mazur,1961 in (Nabil, M. 2005) . States that extraction with an alkaline solution at high temperatures causes a denatured protein. The protein denatured at alkaline $\mathrm{pH}$ then the molecule is present as a soluble protein ( Nabil, M. 2005)

This is suspected in acid-alkaline conditions during boiling with high temperatures to increase solubility of protein in bone so that insoluble calcium under alkaline conditions will be left behind and settle in bone matrices so as to increase the proportion of calcium in the material (fish bone powder). According to Karmas (1982), the effectiveness of the alkaline solution depends on the concentration of the alkaline solution, the temperature used, duration extraction .

\section{d. Protein Content Analysis Result of Milkfish Bone Nano Calcium}

The results of protein content analysis with acidalkaline extract treatment ranged from 0.67 to 3.90 percentage with an average value of 2.04 percentage. The highest protein content was obtained in the treatment of acid extraction method with 20 percentage $\mathrm{HCl}$ cooking at $100{ }^{\circ} \mathrm{C}$ for 60 minutes with a value of 3.56 percentage and the lowest protein content was obtained in the treatment of alkaline extraction methods by cooking $\mathrm{NaOH} 4$ percentage at $100{ }^{\circ} \mathrm{C}$ for 60 minutes with Value of 0.80 percentage.

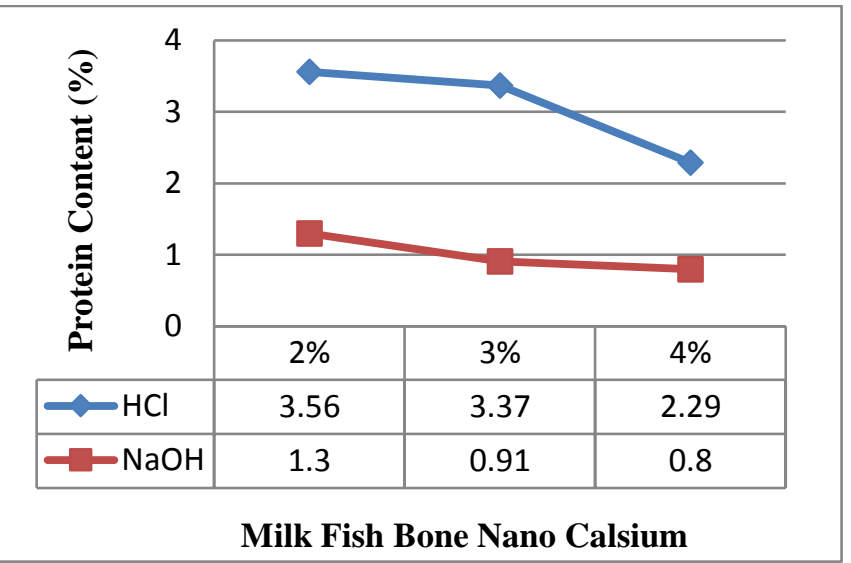

Figure 4. Protein Content Analysis Result of Milkfish Bone Nano Calcium by Acid Alkaline Method

Figure 4 shows that the protein content of fishbone nano calcium protein from all treatments decreased, both treatment of acid and alkaline extraction methods. According to (Nabil. M, 2005 ) states that in making fish bone powder, protein content is removed as much as possible by the process of protein 
hydrolysis using acid and alkaline solutions. This protein removal intended to increase the mineral / ash content contained in the flour. This is presumably because there is still a protein content of bone powder caused by the lack of perfect deproteinize process in making of milkfish bone nano calcium . While result research (Anggraeni N., et all , 2016) with alkaline method is 0,21 percentage lower from this research .

This could proved at treatment autoclaving for 1 hour . Calcium content of Tuna fish bone flour more and more increasing along with decreasing protein content This could proved at treatment autoclaving for 1 hour . protein content of milkfish bone flour with hydrolysis the alkaline $(\mathrm{NaOH}))$ lower because $\mathrm{NaOH}$ can hydrolysis protein in fish bone. For increasing content calcium at the "Tuna" fish bone flour took separation protein with calcium through deproteinase (Wardani, et all, 2012). Calcium content of Tuna fish bone flour more and more increasing along with decreasing protein content

Variance analysis result of protein content with treatment of acid-alkaline extraction method significant value less than 5 percentage $\mathrm{H}_{1}$ accepted and $\mathrm{H}_{0}$ rejected. This means there is a difference between the treatments tested.

\section{e. Sensory Test Analysis (Color) of Milkfish Bone Nano Calcium}

The average analysis of Sensory Test (Color) of milkfish bone nano calcium shows panelist value 3,9 (like). The highest level of Sensory Test (Color) obtained on the treatment of base extraction method with 4 percentage $\mathrm{NaOH}$ cooking at $100{ }^{\circ} \mathrm{C}$ for 60 minutes. The panelist gave the likes of 4.5 and the lowest Sensory (Color) test obtained on the treatment of acid extraction methods $\mathrm{HCl} 2$ percentage with temperature $100^{\circ} \mathrm{C}$ for 60 minutes panelists give the normal value / neutral value is 3.3 . Sensory Test Result (Color) The resulting milkfish bone nano calcium is the preferred criterion. This is thought to be due to a Millard reaction that can cause brown color and high mineral content in milkfish bone nano calcium. The high content of minerals in a foodstuff will affect the color of the resulting product

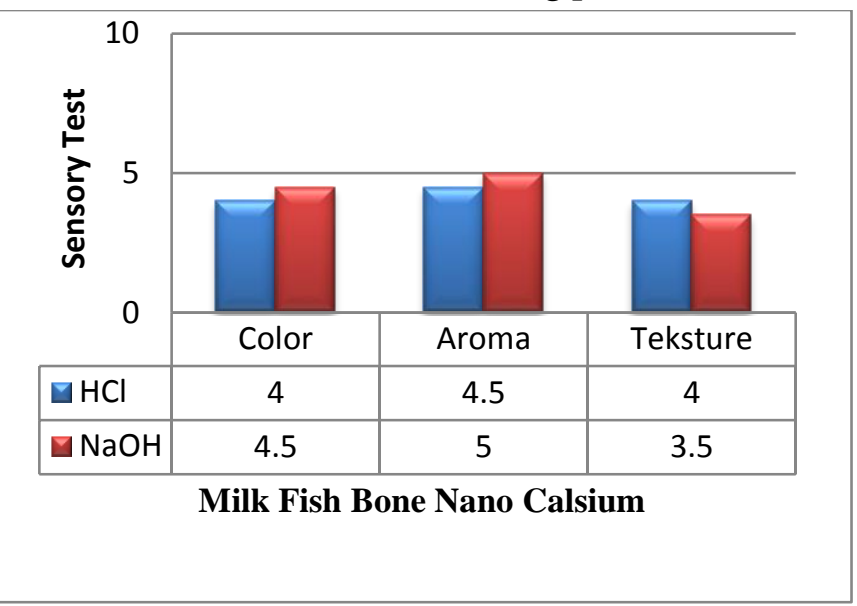

Figure 5. Sensory Test Analysis of Milkfish Bone Nano Calcium

Figure 5 shows that the Sensory Test (Color) of the milkfish bone nano calcium from all treatment levels of consumer acceptance increases. The colors received by the panelists are at a value of 3 (normal) to 4.5 (very like). Differences in the color of the flour produced is also caused by the treatment of heating during the drying process.

The results also show that the higher concentration of $\mathrm{NaOH}$ used tends to increase the degree of white. The higher the concentration of $\mathrm{NaOH}$ used, the more fat and protein content lost so it will tend to increase the degree of white in fish bone. the use of alkaline is more advantageous than the acid (Nabil, M. 2005). The use of a base as a hydrolysis agent produces whiter soluble fraction and insoluble fraction. The weakness of acid use is the formation of blackish brownish or blackish substance called humin or melanin formed from the content of the 
indole core tryptophan with aldehyde derived from carbohydrates contained in the material.

Result of average analysis of Sensory Test (Aroma) milkfish bone nano calcium show panelist value 4,6 (very like). The highest concentration of Sensory Test (Aroma) was obtained on the treatment of base method with 40 percentage $\mathrm{NaOH}$ cooking at $100^{\circ} \mathrm{C}$ for 60 minutes. The panelist gave a very like value of 5 and the lowest Sensory (Aroma) test was obtained on the treatment of acidic method with 20 percentage $\mathrm{HCl}$ cooking At a temperature of $100^{\circ} \mathrm{C}$ for 60 minutes the panelist gives a liking value of 4.2. This is because the resulting aroma is very distinctive., the fragrance-forming components in fishery products are proteins, polysaccharides, pigments and vitamins. added that the flavor of fishy odor is a distinctive odor of fish caused by nitrogen components other than fish protein

Figure 5 shows that the Sensory Test (Aroma) of milkfish bone nano calcium from all treatments increased. The aroma received by the panelist is on the value of 4 (Likes) to 5 (very like).

\section{CONCLUSIONS}

The research result conclusions of milkfish bone nano calcium by using alkaline extraction and acid extraction are the following:

1. Base extraction with $\mathrm{NaOH}$ has a significant effect on water content, ash content, calcium levels, protein content

2. The best milkfish bone powder nano calcium is alkaline extraction with 4 percentage $\mathrm{NaOH}$ cooking at $100^{\circ} \mathrm{C}$ for 60 minutes where the water content is 5.21 percentage. The ash content is 52.87 percentage, the calcium content is 46.13 percentage, the protein content is 2.04 percentage and the color sensory test is 3.9 (Likes), aroma 4,6 (very like) and texture3,6 (likes).

\section{REFERENCES}

[1]. Almatsier. 2004. Basic Principle of Nutrient Science. PT Gramedia Pustaka Utama, Jakarta

[2]. Anggraeni N., Yudhomenggolo, Sastro D., dan Putut H.R., 2016 . Utilization Nanocalcium of "Nila" Oreochromis niloticus) Fish Bone on Analog hulled rice from many kinds Sweet Potato (Ipomoea batatas L.).Journal Techonoly Application ;5(4)

[3]. Association Official Analitical Chemistry. 2000. Official Methods of Analysis. Arlington, New York

[4]. Apriyantono A., Fardiaz D., Puspitasari NL., Sedarnawati, Budiyanto S., 1989. Pusat Antar Universitas Pangan dan Gizi. Institut Pertanian Bogor

[5]. Basmal J, Yeni Y, Murdinah, Suherman M, Gunawan B. 2000. Technical Report. Product Processing Research and Economics and Social. Jakarta

[6]. Cucikodana Y. 2013. The Boiling Temperature Different Effect and $\mathrm{NaOH}$ Concentration of Quality Snakefish (Channastriata) Bone Powder (Mini Thesis) Inderalaya : Agriculture Faculty of Sriwijaya University

[7]. Elfauziah R.2003. Separation Calcium from Bone and Head of "Patin" Fish (Pangasius sp.).(Mini Thesis) Fishery and Ocean Science. IPB.Bogor. National Standardization for Bone Powder . SNI 01-3158-1992. Jakarta: National Standardization Council

[8]. Ferazumma H., Sri A. M., Amalia dan Laily, A., 2011. Substutisi tepung kepala ikan lele dumbo (Clarias gariepinus) untuk 
meningkatkan kandungan kalsium crackers . Jurnal Gizi dan Pangan 6 (1):18-27

[9]. Hafiludin 2015. Nutrient Contain of Milkfish Who who Come From The Different Habitat . Ocean Journal Volume 8 No 1 April 2015. ISSN 1907-9931

[10]. International Seafood of Alaska ISA]. 2002. Analysis of Fish Powders.www.kodiak.com

[11]. Lekahena V., D.N. Faridah., R. Syarief dan R. Peranginangin. 2014.Characteristics of Nano Calcium Physical Chemistry Result Extraction "Nila " Fish Bone with Using Alkaline and acid Solution. Journal Technology and Food Industry 25 (1), 57-64

[12]. Ocean and Fishery Ministery (2011) Ocean and Fishery in Number. Ocean and Fishery Minister. Jakarta

[13]. Ocean and Fishery Minister , 2011. Increasing of Shrimp Production

[14]. Maulida, N. 2005. Utilization Powder Bone of Madidihang Fish (Thunnus albacores) is Supplement in Making Crackers (Mini thesis) Bogor. Ocean and Fishery Faculty IPB

[15]. Mohanraj VJ., Chen Y., 2006. Nanoparticle-a review Trop J Pharma Res 5 :561-573

[16]. Mulia. 2004. Potential Study of "Patin (Pangasiussp) Fish Bone Waste is Course Calcium Alternative in Dry Mie Product (Mini Thesis) Bogor. Fishery and Ocean Science IPB.

[17]. Nabil, M. 2005. Utilization waste of "Tuna" Fish (Thunnus sp.) Bone is Calcium Source with Protein Hydrolysis Method (Mini Thesis) Bogor. Faculty Fishery and Ocean Science IPB

[18]. Sokartono.S.T., 1985. Sensory Assesment . Bhatara Karya Aksara Publisher. Jakarta

[19]. Wardani,Dini, Liviawaty dan Junianto, 2012. Fortifikasi tepung tulang ikan tuna sebagai sumber kalsium terhadap donat .Jurnal Perikanan dan kelautan 3(4):41-50
[20]. Winarno, F. G., F. Srikandi dan D. Fardiaz. 1988. Food Technology Introduction. PT Gramedia Pustaka Utama. Jakarta

[21]. Winarno, F. G., F. Srikandi dan D. Fardiaz.. 2002 Food and Nutrient Chemistry. Jakarta. PT Gramedia Pustaka Utama

\section{Cite this article as :}

Muhammad Fitri, Mursalim, Amran Laga and Zainal , "Characteristic of Milkfish (Chanos - Chanos Forks) Bone Nanocalcium by Acids and Alkaline Extraction", International Journal of Scientific Research in Science and Technology (IJSRST), Online ISSN : 2395-602X, Print ISSN : 2395-6011, Volume 6 Issue 4, pp. 251-260, July-August 2019. Available at doi : https://doi.org/10.32628/IJSRST196444 Journal URL : http://ijsrst.com/IJSRST196444 